\title{
Association of $L T \beta R$ gene polymorphisms with prostate volume in benign prostatic hyperplasia in the Korean population
}

\author{
S.H. Lee ${ }^{1}$, S.K. Kim², K.H. Yoo', J.H. Chung ${ }^{2}$ and S.G. Chang' \\ ${ }^{1}$ Departments of Urology, Kyung Hee University, Seoul, Republic of Korea \\ ${ }^{2}$ Kohwang Medical Research Institute and Department of Pharmacology, \\ School of Medicine, Kyung Hee University, Seoul, Republic of Korea \\ Corresponding author: S.G. Chang \\ E-mail: sgchang@khu.ac.kr
}

Genet. Mol. Res. 14 (4): 18607-18615 (2015)

Received August 17, 2015

Accepted October 22, 2015

Published December 28, 2015

DOI http://dx.doi.org/10.4238/2015.December.28.9

\begin{abstract}
The lymphotoxin- $\beta$ receptor $(L T \beta R)$ gene is involved in autoimmune disease and inflammatory disorder development, but the relationship between $L T \beta R$ and benign prostatic hyperplasia $(B P H)$ is unclear. In total, 222 with $\mathrm{BPH}$ were examined for 3 single nucleotide polymorphisms [rs3759333 (-1387C/T), rs3759334 (-1326A/G), and rs2364480 (Ala172Ala)] located in the promoter and coding regions of $L T \beta R$ using direct sequencing. The genotype distributions of rs3759334 were associated with prostate volume larger than $40 \mathrm{~g}$. There were significant differences between the small $(<40 \mathrm{~g})$ and large $(\geq 40 \mathrm{~g})$ group subjects [codominant 1 model: odds ratio $(\mathrm{OR})=4.65,95 \%$ confidence interval $(\mathrm{Cl})=1.95-11.09, \mathrm{P}=0.001$; dominant model: $\mathrm{OR}=4.91,95 \% \mathrm{Cl}$ $=2.07-11.63, \mathrm{P}=0.0002$; log-additive model: $\mathrm{OR}=4.81,95 \% \mathrm{Cl}=2.05-$ $11.24, \mathrm{P}=0.0001]$. The allele distributions of $\mathrm{rs} 3759334$ were significantly associated with $\mathrm{BPH}(\mathrm{OR}=4.87,95 \% \mathrm{Cl}=2.16-10.99, \mathrm{P}=0.0001)$. The distribution of rs2364480 was significantly different between groups (codominant 1 model: $\mathrm{OR}=2.17,95 \% \mathrm{Cl}=1.11-4.26, \mathrm{P}=0.028$; dominant model: $\mathrm{OR}=2.16,95 \% \mathrm{Cl}=1.13-4.12, \mathrm{P}=0.019 ;$ log-additive model: $\mathrm{OR}$
\end{abstract}


$=1.86,95 \% \mathrm{Cl}=1.07-3.24, \mathrm{P}=0.027)$. The allele distribution of $\mathrm{rs} 2364480$ was significantly associated with $\mathrm{BPH}(\mathrm{OR}=1.88,95 \% \mathrm{Cl}=1.08-3.30, \mathrm{P}$ $=0.027$ ). We found that $L T \beta R$ polymorphisms caused severe $\mathrm{BPH}$. Thus, $L T \beta R$ may contribute to the risk of $\mathrm{BPH}$ development.

Key words: Benign prostatic hyperplasia; Lymphotoxin beta receptor; Polymorphism; Prostate

\section{INTRODUCTION}

Benign prostatic hyperplasia $(\mathrm{BPH})$ is a pathological change that causes lower urinary tract symptoms and is one of the most common urologic diseases in older men (Yoo et al., 2010; Huh et al., 2013). Studies from western countries have reported that the prevalence of BPH is $40-$ $50 \%$ by age 50 years and nearly $80 \%$ by age 70 years (Burnett and Wein, 2006). Research from Korea showed that the prevalence of $\mathrm{BPH}$ is increasing rapidly.

At present, more than one million patients are prescribed BPH medication such as alphablockers and 5-alpha reductase inhibitors (Kang et al., 2011, Shin et al., 2012). Enlargement of the prostate and its progression result in various voiding symptoms, such as frequency, tenesmus, urgency, weak urinary stream, nocturia, and acute urinary retention. The incidence of these symptoms increases rapidly with age, influencing the quality of life and healthcare costs for the elderly (Kwon et al., 2013).

Although many studies have examined the pathogenesis of $\mathrm{BPH}$, it remains unclear. However, inflammation appears to play a role in BPH development and progression. Acute or chronic inflammation is often observed in BPH specimens (Nickel et al., 1999). Some research has shown that inflammatory cytokines, such as interleukin (IL)-2, IL-7, and interferon- $\mathrm{y}$, are overexpressed in BPH tissue (Kramer et al., 2002). Furthermore, recent studies have shown that nitric oxide synthase 2, IL-10, and IL-10RB gene polymorphisms are associated with BPH (Yoo et al., 2010, 2011).

Lymphotoxin (LT), which was first identified in 1968, is a cytotoxic molecule produced by lymphocytes. Because it causes necrosis in various tumor types in vivo, LT was subsequently referred to as tumor necrosis factor. Further studies determined that $L T$ is a member of the tumor necrosis factor family of cytokines (Wolf et al., 2010). In the physiological state, LT is expressed by T-, B-, natural killer-, and lymphoid tissue-inducer cells (Aggarwal et al., 2003). LTa mRNA expression is inducible in B-cells. In contrast, $L T \beta$ mRNA is produced constitutively (Browning et al., 1993). Further investigations showed that LT plays a role in the development of autoimmune diseases and inflammatory disorders (Kratz et al., 1996; Gommerman and Browning, 2003). The LT- $\beta$ receptor $(L T \beta R)$ signaling pathway is known to be required for the homeostatic control of high endothelial venule differentiation and function (Browning et al., 2005). Moreover, this pathway activates gene transcription programs and cell death, which are important in immune development and host defenses (Norris and Ware, 2007).

Few studies have investigated the relationship between LT and prostate cancer, particularly castration-resistant prostate cancer (Ammirante et al., 2010, Wolf et al., 2010). There have been no studies examining the association between $L T \beta R$ and other prostate disease, such as $\mathrm{BPH}$. Because the $L T \beta R$ signaling pathway is important for regulating endothelial differentiation and function, $L T \beta R$ may be related to $B P H$. In this study, we investigated the impact of $L T \beta R$ single nucleotide polymorphisms (SNPs) on BPH. 


\section{MATERIAL AND METHODS}

\section{Subjects}

The present study included 222 patients who had been diagnosed with BPH for the first time. Patients were recruited from Kyung Hee University Medical Center between January 2002 and December 2008 and written informed consent was obtained before the study. All healthy control patients underwent screening for BPH or prostate cancer. All had a normal serum prostate-specific antigen (PSA) level $(<4 \mathrm{ng} / \mathrm{mL}$ ). The patients with $\mathrm{BPH}$ were complaining of moderate to severe lower urinary tract symptoms. Lower urinary tract symptoms were assessed using the International Prostate Symptom Score (IPSS). Uroflowmetry was performed to measure peak urinary flow rate (Qmax) for all patients. Serum PSA levels were evaluated in all BPH patients. Patients with serum PSA level above $4 \mathrm{ng} / \mathrm{mL}$ underwent transrectal ultrasound-guided prostate biopsy to exclude prostate cancer. Prostate size was calculated by transrectal ultrasound. Exclusion criteria for this study were prostate cancer, neurogenic bladder, urinary tract infection, uncontrolled diabetes mellitus, and cardiovascular disease. All patients with BPH were divided into 2 groups based on several multicenter studies: low (0-19) and high ( $\geq 20)$ IPSS group, low $(<1.5 \mathrm{ng} / \mathrm{mL})$ and high $(\geq 1.5 \mathrm{ng} / \mathrm{mL})$ PSA level, low $(<10 \mathrm{~mL} / \mathrm{s})$ and high $(\geq 10 \mathrm{~mL} / \mathrm{s})$ Qmax, and small $(<40 \mathrm{~mL})$ and large $(\geq 40 \mathrm{~mL}$ ) prostate volume (Table 1). This study was approved by the Institutional Review Board at Kyung Hee University Medical Center.

\section{Genotyping}

We investigated SNPs in the promoter and coding regions of LTRR. The 3 SNPs were investigated in a previous study (Kim et al., 2012). Genomic DNA was extracted from blood samples collected in EDTA using a DNA extraction kit (Roche, Basel, Switzerland). Genomic DNA was amplified using specific primers for each SNP (Kim et al., 2012). Polymerase chain reaction conditions consisted of 38 cycles at $94^{\circ} \mathrm{C}$ for $30 \mathrm{~s}, 58^{\circ} \mathrm{C}$ for $30 \mathrm{~s}$, and $72^{\circ} \mathrm{C}$ for $30 \mathrm{~s}$, followed by 1 cycle at $72^{\circ} \mathrm{C}$ for $5 \mathrm{~min}$ to terminate the reaction. The amplification products were sequenced using an ABI PRISM 3730XL analyzer (PE Applied Biosystems, Foster City, CA, USA). Sequencing data were analyzed using the SeqMan II software (DNASTAR Inc., Madison, WI, USA).

\section{Statistical analysis}

SNPStats (http://bioinfo.iconcologia.net/index.php) and SPSS 18.0 (SPSS Inc., Chicago, IL, USA) were used to determine the odds ratio (OR), 95\% confidence interval $(\mathrm{Cl})$, and $\mathrm{P}$ value adjusted for age as covariables. Multiple-logistic regression models (codominant 1, codominant 2, dominant, recessive, and log-additive models) were applied (Yoo et al., 2011).

\section{RESULTS}

\section{Characteristics}

Characteristics of enrolled patients are shown in Table 1. The mean age was $65.52 \pm 10.3$ years. The mean IPSS, PSA, Qmax, and total prostate volume were $17.31 \pm 0.56,4.58 \pm 0.36$ 
$\mathrm{ng} / \mathrm{mL}, 11.22 \pm 0.40 \mathrm{~mL} / \mathrm{s}$, and $38.97 \pm 1.46 \mathrm{~mL}$, respectively. Based on our definition, the small prostate group included $147(66.2 \%)$ patients, while the large group included $75(33.8 \%)$ patients. The low IPSS group included $123(61.2 \%)$ patients and the high IPSS group included 78 (38.8\%) patients. In total, 75 patients were included in the low PSA group and 117 patients were included in the high PSA group.

Table 1. Clinical characteristics of the patients.

\begin{tabular}{lc}
\hline & Mean \pm SE \\
\hline Age (years) & $65.52 \pm 10.3$ \\
IPSS & $17.31 \pm 0.56$ \\
QoL & $3.61 \pm 0.10$ \\
PSA $(\mathrm{ng} / \mathrm{mL})$ & $4.58 \pm 0.36$ \\
Free PSA $(\mathrm{ng} / \mathrm{mL})$ & $1.00 \pm 0.08$ \\
Qmax $(\mathrm{mL} / \mathrm{s})$ & $11.22 \pm 0.40$ \\
Qavg $(\mathrm{mL} / \mathrm{s})$ & $6.55 \pm 0.26$ \\
VV $(\mathrm{mL})$ & $213.60 \pm 13.19$ \\
PVR $(\mathrm{mL})$ & $63.11 \pm 7.12$ \\
Total prostate volume $(\mathrm{mL})$ & $38.97 \pm 1.46$ \\
Inner prostate volume $(\mathrm{mL})$ & $18.58 \pm 1.29$ \\
\hline
\end{tabular}

*SE = standard error; IPSS = International Prostate Symptom Score; QoL = quality of life; PSA = prostate-specific antigen; $\mathrm{Qmax}=$ peak urinary flow rate; $\mathrm{Qavg}=$ average urinary flow rate; $\mathrm{VV}=$ voided volume; $\mathrm{PVR}=$ post-void residual urine.

\section{Prostate volume and $L T \beta R$ gene polymorphisms}

Analyses of genotype frequencies in $L T \beta R$ gene polymorphisms based on prostate volume are shown in Table 2. Genotype distributions of rs3759333 and rs2364480 showed no association with prostate volume $(P>0.05)$. Alleles of these SNPs were not related to prostate volume $(P>$ 0.05). However, genotype distributions of the rs3759334 SNP showed a significant association with prostate volume. The distributions of genotypes and alleles of rs3759334 for the small group and large group were analyzed. We found significant differences between small and large group subjects $(\mathrm{OR}=4.65,95 \% \mathrm{Cl}=1.95-11.09, \mathrm{P}=0.001$ in the codominant 1 model; $\mathrm{OR}=4.91,95 \% \mathrm{Cl}$ $=2.07-11.63, \mathrm{P}=0.0002$ in the dominant model; $\mathrm{OR}=4.81,95 \% \mathrm{Cl}=2.05-11.24, \mathrm{P}=0.0001$ in the log-addictive model). The allele distributions of the rs3759334 SNP were significantly associated with $\mathrm{BPH}(\mathrm{OR}=4.87,95 \% \mathrm{Cl}=2.16-10.99, \mathrm{P}=0.0001)$.

\section{IPSS and $L T \beta R$ gene polymorphisms}

Genotype distributions of the SNPs (rs3759333, rs3759334, and rs2364480) for the high and low IPSS groups were analyzed. The distributions of genotypes and alleles of rs3759333 and rs3759334 were not associated with BPH $(P>0.05)$. However, the distribution of the rs2364480 SNP was significantly different between groups $(\mathrm{OR}=2.17,95 \% \mathrm{Cl}=1.11-4.26, \mathrm{P}=0.028$ in the codominant 1 model; $\mathrm{OR}=2.16,95 \% \mathrm{Cl}=1.13-4.12, \mathrm{P}=0.019$ in the dominant model; $\mathrm{OR}=1.86$, $95 \% \mathrm{Cl}=1.07-3.24, \mathrm{P}=0.027$ in the log-additive model). The allele distribution of the $\mathrm{rs} 2364480$ SNP was significantly associated with $\mathrm{BPH}(\mathrm{OR}=1.88,95 \% \mathrm{Cl}=1.08-3.30, \mathrm{P}=0.027)($ Table 3$)$.

\section{Relationships between prostate volume, IPSS, total PSA, and Qmax}

We demonstrated that the rs3759334 SNP was related to prostate volume and total PSA. The correlation coefficients between prostate volume and total PSA and the rs3759334 SNP were 
Table 2. Analysis of genotype distributions and allele frequencies in $L T \beta R$ gene polymorphisms, based on prostate volume in subjects with $\mathrm{BPH}$.

\begin{tabular}{|c|c|c|c|c|c|c|}
\hline SNP & Genotype/allele & $\begin{array}{c}\text { Prostate volume }(<40 \mathrm{~mL}) \\
\mathrm{N}(\%)\end{array}$ & $\begin{array}{c}\text { Prostate volume }(\geq 40 \mathrm{~mL}) \\
\mathrm{N}(\%)\end{array}$ & Models & OR $(95 \% \mathrm{Cl})$ & $P$ value \\
\hline rs3759333 & $\mathrm{C} / \mathrm{C}$ & 49 (33.3) & $17(22.7)$ & Codominant 1 & $1.82(0.92-3.58)$ & 0.083 \\
\hline \multirow[t]{6}{*}{$-1387 \mathrm{C} / \mathrm{T}$} & $\mathrm{C} / \mathrm{T}$ & $68(46.3)$ & $45(60.0)$ & Codominant 2 & $1.24(0.52-2.94)$ & 0.63 \\
\hline & $T / T$ & $30(20.4)$ & $13(17.3)$ & Dominant & $1.64(0.86-3.15)$ & 0.13 \\
\hline & & & & Recessive & $0.83(0.40-1.73)$ & 0.62 \\
\hline & & & & Log-additive & $1.16(0.77-1.75)$ & 0.47 \\
\hline & C & $166(56.5)$ & 79 (52.7) & & 1 & \\
\hline & $\mathrm{T}$ & $128(43.5)$ & $71(47.3)$ & & $1.17(0.79-1.73)$ & 0.447 \\
\hline rs3759334 & G/G & $138(93.9)$ & $56(74.7)$ & Codominant 1 & $4.65(1.95-11.09)$ & 0.001 \\
\hline \multirow[t]{6}{*}{$-1326 A / G$} & $\mathrm{G} / \mathrm{A}$ & $9(6.1)$ & $18(24)$ & Codominant 2 & $N A(0.00-N A)$ & NA \\
\hline & $\mathrm{A} / \mathrm{A}$ & $0(0.0)$ & $1(1.3)$ & Dominant & $4.91(2.07-11.63)$ & 0.0002 \\
\hline & & & & Recessive & NA $(0.00-N A)$ & NA \\
\hline & & & & Log-additive & $4.81(2.05-11.24)$ & 0.0001 \\
\hline & G & $285(96.9)$ & $130(86.7)$ & & 1 & \\
\hline & A & $9(3.1)$ & $20(13.3)$ & & $4.87(2.16-10.99)$ & 0.0001 \\
\hline rs2364480 & $\mathrm{A} / \mathrm{A}$ & $105(71.9)$ & $60(80.0)$ & Codominant 1 & $0.67(0.33-1.35)$ & 0.259 \\
\hline \multirow[t]{6}{*}{ Ala172Ala } & $\mathrm{A} / \mathrm{C}$ & $36(24.7)$ & 14 (18.7) & Codominant 2 & $0.41(0.05-3.59)$ & 0.417 \\
\hline & $\mathrm{C} / \mathrm{C}$ & $5(3.4)$ & $1(1.3)$ & Dominant & $0.64(0.32-1.26)$ & 0.19 \\
\hline & & & & Recessive & $0.44(0.05-3.91)$ & 0.43 \\
\hline & & & & Log-additive & $0.66(0.36-1.21)$ & 0.16 \\
\hline & A & $246(84.2)$ & $134(89.3)$ & & 1 & \\
\hline & $\mathrm{C}$ & $46(15.8)$ & $16(10.7)$ & & $0.64(0.35-1.17)$ & 0.147 \\
\hline
\end{tabular}

* $L T \beta R=$ lymphotoxin beta receptor; $\mathrm{BPH}=$ benign prostatic hyperplasia; $\mathrm{SNP}=$ single nucleotide polymorphism; OR = odds ratio; $\mathrm{Cl}$ = confidence interval; $\mathrm{N}=$ number; $\mathrm{NA}=$ not applicable. Bold characters indicate statistically significant values.

Table 3. Analysis of genotype frequencies in $L T \beta R$ polymorphisms, based on $(<19)$ IPSS and $(\geq 20)$ IPSS, in subjects with $\mathrm{BPH}$.

\begin{tabular}{|c|c|c|c|c|c|c|}
\hline SNP & Genotype/allele & $\begin{array}{c}\text { IPSS }(<19) \\
N(\%)\end{array}$ & $\begin{array}{c}\text { IPSS }(\geq 20) \\
N(\%)\end{array}$ & Models & OR $(95 \% \mathrm{Cl})$ & $P$ \\
\hline rs3759333 & $\mathrm{C} / \mathrm{C}$ & $35(28.5)$ & $24(30.8)$ & Codominant 1 & $1.06(0.55-2.03)$ & 0.87 \\
\hline \multirow{6}{*}{$-1387 \mathrm{C} / \mathrm{T}$} & $\mathrm{T} / \mathrm{C}$ & $59(48)$ & $44(56.4)$ & Codominant 2 & $0.50(0.20-1.21)$ & 0.13 \\
\hline & $T / T$ & $29(23.6)$ & $10(12.8)$ & Dominant & $0.87(0.47-1.63)$ & 0.67 \\
\hline & & & & Recessive & $0.48(0.22-1.06)$ & 0.06 \\
\hline & & & & Log-additive & $0.75(0.50-1.14)$ & 0.18 \\
\hline & C & $129(52.4)$ & $92(59.0)$ & & 1 & \\
\hline & $\mathrm{T}$ & 117 (47.6) & $64(41.0)$ & & $0.78(0.51-1.15)$ & 0.20 \\
\hline rs3759334 & $G / G$ & $109(88.6)$ & 66 (84.6) & Codominant 1 & $1.44(0.61-3.37)$ & 0.40 \\
\hline \multirow[t]{6}{*}{$-1326 A / G$} & $A / G$ & 13 (10.6) & $12(15.4)$ & Codominant 2 & $0.00(0.00-\mathrm{NA})$ & NA \\
\hline & $\mathrm{A} / \mathrm{A}$ & $1(0.8)$ & $0(0)$ & Dominant & $1.34(0.58-3.09)$ & 0.50 \\
\hline & & & & Recessive & 0.00 (0.00-NA) & NA \\
\hline & & & & Log-additive & $1.21(0.55-2.68)$ & 0.64 \\
\hline & G & 231 (93.9) & $144(92.3)$ & & 1 & \\
\hline & A & $15(6.1)$ & $12(7.7)$ & & $1.28(0.58-2.82)$ & 0.53 \\
\hline rs2364480 & $\mathrm{A} / \mathrm{A}$ & 98 (79.7) & $50(64.9)$ & Codominant 1 & $2.17(1.11-4.26)$ & 0.028 \\
\hline \multirow[t]{6}{*}{ Ala172Ala } & $\mathrm{A} / \mathrm{C}$ & $22(17.9)$ & $24(31.2)$ & Codominant 2 & $2.11(0.41-10.94)$ & 0.38 \\
\hline & $\mathrm{C} / \mathrm{C}$ & $3(2.4)$ & 3 (3.9) & Dominant & $2.16(1.13-4.12)$ & 0.019 \\
\hline & & & & Recessive & $1.73(0.34-8.86)$ & 0.51 \\
\hline & & & & Log-additive & $1.86(1.07-3.24)$ & 0.027 \\
\hline & A & $218(88.6)$ & $124(80.5)$ & & 1 & \\
\hline & C & $28(11.4)$ & $30(19.5)$ & & $1.88(1.08-3.30)$ & 0.027 \\
\hline
\end{tabular}

${ }^{*} L T \beta R=$ lymphotoxin beta receptor; IPSS = International Prostate Symptom Score; $\mathrm{BPH}=$ benign prostatic hyperplasia; $\mathrm{SNP}=$ single nucleotide polymorphism; $\mathrm{OR}=$ odds ratio; $\mathrm{Cl}=$ confidence interval; $\mathrm{N}=$ number; $\mathrm{NA}=$ not applicable. Bold characters indicate statistically significant values. 
0.244 and $0.152(P<0.001, P=0.024)$, respectively. Thus, prostate volume, total $P S A$, and the rs3759334 SNP were slightly associated. However, rs3759334 SNP showed no relationship with IPSS or Qmax. In contrast, the rs3759333 SNP was related to Qmax. The correlation coefficient between Qmax and the rs3759333 SNP was $-0.152(P=0.028)$. The relationship between all factors and the rs2364480 SNP was not significant $(P>0.05$; Table 4).

\begin{tabular}{|c|c|c|c|c|c|c|c|c|c|c|c|c|c|c|}
\hline \multirow[t]{2}{*}{ SNP } & \multirow[t]{2}{*}{ Genotype } & \multirow[t]{2}{*}{$\mathrm{N}$} & \multicolumn{3}{|c|}{ Prostate volume } & \multicolumn{3}{|c|}{ IPSS } & \multicolumn{3}{|c|}{ Total PSA } & \multicolumn{3}{|c|}{ Qmax } \\
\hline & & & Mean \pm SD & $\begin{array}{l}\text { Pearson } \\
\text { correlation }\end{array}$ & $\mathrm{P}$ & Mean \pm SD & $\begin{array}{l}\text { Pearson } \\
\text { correlation }\end{array}$ & $P$ & Mean \pm SD & $\begin{array}{l}\text { Pearson } \\
\text { correlation }\end{array}$ & $P$ & Mean \pm SD & $\begin{array}{l}\text { Pearson } \\
\text { correlation }\end{array}$ & $P$ \\
\hline \multirow{3}{*}{$\begin{array}{l}\text { rs3759333 } \\
-1387 \mathrm{C} / \mathrm{T}\end{array}$} & $\mathrm{C} / \mathrm{C}$ & 66 & $34.71 \pm 20.38$ & \multirow[t]{3}{*}{0.057} & \multirow[t]{3}{*}{0.40} & $17.50 \pm 8.51$ & \multirow[t]{3}{*}{-0.069} & \multirow[t]{3}{*}{0.33} & $4.23 \pm 4.55$ & \multirow[t]{3}{*}{0.006} & \multirow[t]{3}{*}{0.93} & $12.31 \pm 6.14$ & \multirow[t]{3}{*}{-0.152} & \multirow[t]{3}{*}{0.028} \\
\hline & $\mathrm{T} / \mathrm{C}$ & 113 & $42.26 \pm 22.98$ & & & $17.82 \pm 7.84$ & & & $4.96 \pm 5.00$ & & & $11.11 \pm 5.40$ & & \\
\hline & $\mathrm{T} / \mathrm{T}$ & 43 & $36.83 \pm 18.83$ & & & $15.66 \pm 6.75$ & & & $4.14 \pm 6.96$ & & & $9.76 \pm 5.68$ & & \\
\hline \multirow{3}{*}{$\begin{array}{l}\text { rs3759334 } \\
-1326 \mathrm{~A} / \mathrm{G}\end{array}$} & $\mathrm{G} / \mathrm{G}$ & 194 & $37.01 \pm 20.71$ & \multirow[t]{3}{*}{0.244} & \multirow[t]{3}{*}{$<0.001$} & $16.92 \pm 7.82$ & \multirow[t]{3}{*}{0.116} & \multirow[t]{3}{*}{0.10} & $4.24 \pm 4.59$ & \multirow[t]{3}{*}{0.152} & \multirow[t]{3}{*}{0.024} & $11.4 \pm 5.92$ & \multirow[t]{3}{*}{-0.134} & \multirow[t]{3}{*}{0.05} \\
\hline & A/G & 27 & $51.85 \pm 23.95$ & & & $20.12 \pm 8.01$ & & & $7.10 \pm 8.63$ & & & $9.56 \pm 3.90$ & & \\
\hline & $\mathrm{A} / \mathrm{A}$ & 1 & $71.00 \pm 0.00$ & & & $15.00 \pm 0.00$ & & & $2.00 \pm 0.00$ & & & $4.00 \pm 0.00$ & & \\
\hline \multirow{3}{*}{ rs2364480 } & $\mathrm{A} / \mathrm{A}$ & 165 & $40.29 \pm 22.00$ & \multirow{3}{*}{$\begin{array}{ll}0 & -0.095 \\
3 & \\
2 & \end{array}$} & \multirow[t]{3}{*}{0.16} & $16.80 \pm 7.60$ & \multirow[t]{3}{*}{0.063} & \multirow[t]{3}{*}{0.38} & $4.64 \pm 5.48$ & \multirow[t]{3}{*}{-0.035} & \multirow[t]{3}{*}{0.60} & $10.91 \pm 5.49$ & \multirow[t]{3}{*}{0.111} & \multirow[t]{3}{*}{0.11} \\
\hline & $\mathrm{A} / \mathrm{C}$ & 50 & $35.68 \pm 21.68$ & & & $18.69 \pm 8.46$ & & & $4.61 \pm 5.11$ & & & $12.23 \pm 6.24$ & & \\
\hline & $\mathrm{C} / \mathrm{C}$ & 6 & $32.00 \pm 7.702$ & & & $17.33 \pm 8.39$ & & & $2.67 \pm 2.24$ & & & $12.50 \pm 7.20$ & & \\
\hline
\end{tabular}

IPSS = International Prostate Symptom Score; PSA = prostate specific antigen; Qmax = peak urinary flow rate; $L T \beta R$ = lymphotoxin beta receptor; SNP = single nucleotide polymorphism; $\mathrm{N}=$ number; $\mathrm{SD}=$ standard deviation. Bold characters indicate statistically significant values.

\section{DISCUSSION}

$\mathrm{BPH}$ is a common, chronic, and progressive disease that is defined as prostatic enlargement secondary to stromal and glandular hyperproliferation of the prostate (Djavan et al., 2011). Several factors such as inflammatory mediators, hormones, diet, inflammatory genes, and oxidative stress have been suggested to play important roles in the development of BPH; however, the primary factor affecting BPH development remains unclear (Bostanci et al., 2013).

Recently, genetic associations between polymorphisms in various genes and $\mathrm{BPH}$ have been examined. Berges et al. (2009) reported an association between polymorphisms in the CYP19A1 and CYP3A4 genes and lower urinary tract symptoms, prostate volume, uroflow, and prostate-specific antigen. In Korea, Yoo et al. (2011) reported associations between IL-10, IL$10 R A$, and $I L-10 R B$ polymorphisms and $\mathrm{BPH}$. In their study, the authors found a strong association between IL-10 SNPs (rs1518111, rs1554286) and IL-10RB SNPs (rs999788, rs2834167) and $\mathrm{BPH}$. The same group found that nitric oxide synthase 2 gene polymorphisms were related to prostate volume in Korean men with BPH. In their study, a strong association between the NOS2 SNP, rs10459953, and prostatic volume in males with BPH was found (Yoo et al., 2010). Other groups have investigated the associations between nitric oxide synthase group polymorphisms and BPH. Lee et al. (2009) reported that the eNOS G894T gene polymorphism was associated with erectile dysfunction and BPH. They found that the eNOS G894T polymorphism was a common and independent risk factor for both erectile dysfunction and BPH in Taiwan and China (Xie et al., 1997). In the present study, we investigated whether $L T \beta R$ polymorphisms were associated with BPH in Korean males and found that the genotype frequency of a promoter SNP (rs3759334, -1326A/G) was associated with prostate volume larger than $40 \mathrm{~g}$. Furthermore, the genotype frequency of the exon SNP (rs2364480, Ala172Ala) was related to IPSS higher than 20. 
Numerous studies have been conducted to examine the association between BPH and inflammation; however, the results of these studies are unclear (Di Silverio et al., 2003; Kramer et al., 2007; Bostanci et al., 2013). A study conducted in Italy reported that $43.1 \%$ (1700 of 3942) $\mathrm{BPH}$ cases had chronic prostate inflammation in histologic prostate specimens (Di Silverio et al., 2003). Additionally, in 2007, Kramer et al. (2007) suggested that chronic inflammation of the prostate not only increases IPSS and the risk of BPH complication, but also leads to prostate enlargement. The study reported that many inflammatory cells, proinflammatory cytokines, infections, or autoimmune conditions are associated with $\mathrm{BPH}$ and concluded that $\mathrm{BPH}$ is an immune inflammatory disease. Moreover, the association between $\mathrm{BPH}$ and inflammatory gene polymorphisms such as IL-2, IL-7, interferon-y, IL-10, IL-10RA, and IL10RB has been reported (Kramer et al., 2002; Yoo et al., 2011). According to the previous reports, inflammation appears to play a role in $\mathrm{BPH}$ development.

Human $L T \beta R$ is a member of the tumor necrosis factor receptor superfamily, which induces the inflammatory response. It is essential for not only the development and organization of secondary lymphoid tissues, but also chemokine release (Chang et al., 2002). Many studies have investigated the roles of LT in lymphoid neogenesis, inflammatory disorders, and autoimmune diseases (Kratz et al., 1996; Luther et al., 2000; Martin et al., 2004). Based on the characteristics of $L T \beta R$, many authors have reported an association between $L T \beta R$ and IgA nephropathy, which is influenced by the immune, inflammation, glomerular protein, and renin-angiotensin systems (Wang et al., 2004; Kim et al., 2012). Kim et al. (2012) identified an association between polymorphisms of $L T \beta R$ (rs3759334, -1326A/G) and IgA nephropathy. Furthermore, they found out that the alleles of the rs3759334 and exon SNPs (rs2364480, Ala172Ala) were risk factors for developing IgA nephropathy.

However, few studies have examined the association between $L T \beta R$ and prostatic disease. Ammirante et al. (2010) found a relationship between $L T \beta R$ and prostate cancer. They found that $L T$ signals $L T \beta R$ in prostate cancer cells to induce inflammation-responsive $I_{\kappa B}$ kinase- $\alpha$ nuclear translocation and STAT3 activation in castration-resistant prostate cancer. This enhances the androgen-independent growth of prostate cancer cells. The inflammatory response, which is activated through $\angle T \beta R$, results in failure of androgen deprivation therapy. Consequently, patients who produced high levels of LT were at higher risk of developing castration-resistant prostate cancer. Thus, anti-LT therapy may have some benefit in castrationresistant prostate cancer patients.

Our study was limited because of the small sample size, making it difficult to generalize the results. However, this is the first study to suggest a relationship between polymorphisms in $L T \beta R$ and $\mathrm{BPH}$. We analyzed the genotype and haplotype distributions of SNPs according to disease progression factors, such as prostate volume, IPSS, and peak flow rate. The results showed that $L T \beta R$ polymorphisms were risk factors for a large prostate volume, a peak flow rate less than 15 $\mathrm{mL} / \mathrm{s}$, and IPSS higher than 20. Based on these results, $L T \beta R$ polymorphisms caused severe $\mathrm{BPH}$, and $L T \beta R$ polymorphisms were associated with BPH. Further studies on other LT $\beta R$ SNPs in large populations are needed to support our result that $L T \beta R$ may contribute to the risk of BPH development.

\section{Conflicts of interest}

The authors declare no conflict of interest. 


\section{REFERENCES}

Aggarwal BB, Kumar A and Bharti AC (2003). Anticancer potential of curcumin: preclinical and clinical studies. Anticancer Res. 23: 363-398.

Ammirante M, Luo JL, Grivennikov S, Nedospasov S, et al. (2010). B-cell-derived lymphotoxin promotes castration-resistant prostate cancer. Nature 464: 302-305

Berges R, Gsur A, Feik E, Hofner K, et al. (2009). Association of polymorphisms in CYP19A1 and CYP3A4 genes with lower urinary tract symptoms, prostate volume, uroflow and PSA in a population-based sample. World J. Urol. 29: 143-148.

Bostanci Y, Kazzazi A, Momtahen S, Laze J, et al. (2013). Correlation between benign prostatic hyperplasia and inflammation. Curr. Opin. Urol. 23: 5-10.

Browning JL, Ngam-ek A, Lawton P, DeMarinis J, et al. (1993). Lymphotoxin beta, a novel member of the TNF family that forms a heteromeric complex with lymphotoxin on the cell surface. Cell 72: 847-856.

Browning JL, Allaire N, Ngam-Ek A, Notidis E, et al. (2005). Lymphotoxin-beta receptor signaling is required for the homeostatic control of HEV differentiation and function. Immunity 23: 539-550.

Burnett AL and Wein AJ (2006). Benign prostatic hyperplasia in primary care: what you need to know. J. Urol. 175: S19-S24.

Chang YH, Hsieh SL, Chen MC and Lin WW (2002). Lymphotoxin beta receptor induces interleukin 8 gene expression via NFkappaB and AP-1 activation. Exp. Cell. Res. 278: 166-174.

Di Silverio F, Gentile V, De Matteis A, Mariotti G, et al. (2003). Distribution of inflammation, pre-malignant lesions, incidental carcinoma in histologically confirmed benign prostatic hyperplasia: a retrospective analysis. Eur. Urol. 43: 164-175.

Djavan B, Margreiter M and Dianat SS (2011). An algorithm for medical management in male lower urinary tract symptoms. Curr. Opin. Urol. 21: 5-12.

Gommerman JL and Browning JL (2003). Lymphotoxin/light, lymphoid microenvironments and autoimmune disease. Nat. Rev. Immunol. 3: 642-655.

Huh JS, Kim YJ and Kim SD (2013). Prevalence of benign prostatic hyperplasia on Jeju Island: analysis from a cross-sectional community-based survey. World J. Mens Health 30: 131-137.

Kang JY, Min GE, Son H, Kim HT, et al. (2011). National-wide data on the treatment of BPH in Korea. Prostate Cancer Prostatic Dis. 14: 243-247.

Kim SK, Lee JY, Jeong Park H, Chung JH, et al. (2012). Association between lymphotoxin beta receptor gene polymorphisms and IgA nephropathy in Korean children. Immunol. Invest. 41: 447-457.

Kramer G, Steiner GE, Handisurya A, Stix U, et al. (2002). Increased expression of lymphocyte-derived cytokines in benign hyperplastic prostate tissue, identification of the producing cell types, and effect of differentially expressed cytokines on stromal cell proliferation. Prostate 52: 43-58.

Kramer G, Mitteregger D and Marberger M (2007). Is benign prostatic hyperplasia (BPH) an immune inflammatory disease? Eur. Urol. 51: 1202-1216.

Kratz A, Campos-Neto A, Hanson MS and Ruddle NH (1996). Chronic inflammation caused by lymphotoxin is lymphoid neogenesis. J. Exp. Med. 183: 1461-1472.

Kwon H, Kang HC and Lee JH (2013). Relationship between predictors of the risk of clinical progression of benign prostatic hyperplasia and metabolic syndrome in men with moderate to severe lower urinary tract symptoms. Urology 81: 1325-1329.

Lee YC, Wu WJ, Liu CC, Wang CJ, et al. (2009). The associations among eNOS G894T gene polymorphism, erectile dysfunction, and benign prostate hyperplasia-related lower urinary tract symptoms. J. Sex. Med. 6: 3158-3165.

Luther SA, Lopez T, Bai W, Hanahan D, et al. (2000). BLC expression in pancreatic islets causes B cell recruitment and lymphotoxin-dependent lymphoid neogenesis. Immunity 12: 471-481.

Martin AP, Coronel EC, Sano G, Chen SC, et al. (2004). A novel model for lymphocytic infiltration of the thyroid gland generated by transgenic expression of the CC chemokine CCL21. J. Immunol. 173: 4791-4798.

Nickel JC, Downey J, Young I and Boag S (1999). Asymptomatic inflammation and/or infection in benign prostatic hyperplasia. BJU Int. 84: 976-981.

Norris PS and Ware CF (2007). The LT beta R signaling pathway. Adv. Exp. Med. Biol. 597: 160-172.

Shin TJ, Kim Cl, Park CH, Kim BH, et al. (2012). a-Blocker monotherapy and a-blocker plus 5-alpha-reductase inhibitor combination treatment in benign prostatic hyperplasia; 10 years' long-term results. Korean J. Urol. 53: 248-252.

Wang J, Anders RA, Wu Q, Peng D, et al. (2004). Dysregulated LIGHT expression on T cells mediates intestinal inflammation and contributes to IgA nephropathy. J. Clin. Invest. 113: 826-835.

Wolf MJ, Seleznik GM, Zeller N and Heikenwalder M (2010). The unexpected role of lymphotoxin beta receptor signaling in carcinogenesis: from lymphoid tissue formation to liver and prostate cancer development. Oncogene 29: 5006-5018.

Xie K, Huang S, Dong Z, Juang SH, et al. (1997). Destruction of bystander cells by tumor cells transfected with inducible nitric oxide (NO) synthase gene. J. Natl. Cancer Inst. 89: 421-427. 
Yoo KH, Kim SK, Chung JH and Chang SG (2010). Nitric oxide synthase 2 gene polymorphisms are associated with prostatic volume in Korean men with benign prostatic hyperplasia. Asian J. Androl. 12: 690-696.

Yoo KH, Kim SK, Chung JH and Chang SG (2011). Association of IL10, IL10RA, and IL10RB polymorphisms with benign prostate hyperplasia in Korean population. J. Korean Med. Sci. 26: 659-664. 